Social Work \& Education

CSW\&E, 2021

УДК 364-3(477):616.9

DOI: $10.25128 / 2520-6230.21 .3 .1$

\section{Ольга Байдарова,} кандидат психологічних наук, доцент кафедри соціальної реабілітації та соціальної педагогіки,

Київський національний університет імені Тараса Шевченка, м. Київ, Україна; baidarovao@knu.ua

ORCID ID: http://orcid.org/ 00000002-5479-1907

\section{Анастасія Дюльгерова, здобувачка освітнього рівня «магістр» за ОНП «Соціальна педагогіка», \\ Київський національний університет імені Тараса Шевченка, м. Київ, Україна; anastasiadyulgerowa@gmail.com}

ORCID ID: https://orcid.org/00000003-2940-9582

\section{Cmamyc cmammi:}

Отримано: серпень 08, 2021

1-иеремензувания: вересень 07, 2021 Прийнято: вересень 30, 2021
Байдарова, О., Дюльгерова, А. (2021). Волонтерська діяльність в україні в умовах пандемії COVID-19. Social Work and Education, Vol. 8, No. 3. pp. 311-328. DOI: 10.25128/2520-6230.21.3.1

\section{ВОЛОНТЕРСЬКА ДІЯЛЬНІСТЬ В УКРАЇНІ В УМОВАХ ПАНДЕМІЇ COVID-19}

\begin{abstract}
Анотація. Пандемія COVID-19 стала серйозним викликом для українського суспільства і позначилась на усіх сферах діяльності, в тому числі - на добровольчій активності громадян. У статті представлено результати дослідження стану та визначення особливостей реалізації волонтерської діяльності в умовах COVID-19 в Україні. Дослідження проводилось у травні-червні 2021 p. iз застосуванням методів метааналізу статистичних даних, анкетування, контент-аналізу.
\end{abstract}

Виявлено, що $60 \%$ офіційно зареєстрованих волонтерських організацій припинили свою діяльність або не можуть бути ідентифіковані як активно діючі. Аналіз та систематизація моніторингових даних, наданих Українською Волонтерською Службою, дозволив виділити 77 організацій різного спрямування, які реально працюють в період карантину та активно залучають волонтерський pecypc. 3 формальних та неформальних організацій, які мають публічні веб-сторінки 3 контактними даними для електронного листування, було опитано 35 осіб.

3'ясовано, що в умовах карантину діяльність організацій, які залучають добровольчий ресурс, змінилася для $54 \%$ опитаних, проте, попри труднощі, які відчувають $80 \%$ організацій, вони продовжують працювати. Неможливість організовувати діяльність, яка передбачає прямий контакт з отримувачем послуги, або ж необхідність додатково подбати про засоби індивідуального захисту і забезпечення безпеки, як для отримувачів послуг, так і для надавачів (волонтерів), виявилися ключовими труднощами в організації роботи волонтерів. Серед основних змін волонтери зазначають зміну форм роботи, перехід у дистанційній формат, зокрема в Інтернет простір, зменшення кількості залучених волонтерів та відмову від проведення деяких заходів, з відкладенням реалізації на невизначений час. Прикметно, що більшість опитаних оцінюють ситуацію 3 карантином як ситуацію можливостей, а не обмежень, зокрема, відзначають появу нових напрямків діяльності, одним.

Ключові слова: волонтерство; COVID-19; нокдаун; криза; цифровізація волонтерської діяльності. 


\section{Вступ}

Волонтерство у світі - розповсюджене явище, що присутнє в багатьох сферах життєдіяльності людини, у різних формах і напрямках. В Україні, яка тривалий час демонструвала досить низькі показники громадської активності, суттєве зростання кількості громадян, залучених до благочинної та волонтерської діяльності, відбулося 32014 року, після подій на Євромайдані та 3 початком військової агресії з боку Росії на сході України (Павлюк, 2015; Паславська, 2016; Козачук, 2016; Чайка, 2017; Проценко, 2021). Волонтерство доповнює функції державних органів, сприяє стабілізації та регулюванню суспільних відносин. Волонтери беруть участь у процесі прийняття рішень та максимально оперативно вирішують проблеми населення. У період кризи, коли поглиблюється дисбаланс між здатністю держави ефективно виконувати свої функції та забезпеченням основних потреб громадян, волонтерська діяльність набуває усіх ознак найбільш дієвої форми самоорганізації населення (Горєлов та Корнієвський, 2016, 16). За екстраординарних обставин волонтери активізуються (Pyrlik, 2020), гнучко застосовують форми та методи діяльності в обхід бюрократичних процедур та впроваджують інноваційні способи вирішення нових проблемних питань.

Одна 3 нових криз виявилася у січні 2020 року. Bipyc SARS-CoV-2 (2019 $\mathrm{nCoV}$ ) швидко поширювався світом. Він викликає захворювання COVID-19, яке може призвести до смерті. Українське суспільство прийняло новий виклик і 3 кожним днем зростала як кількість заражених, так і кількість людей, які бажають допомогти медичним закладам та установам. Пандемія створила нові напрямки для волонтерської роботи, що, в свою чергу, призвело до створень організацій, об'єднань громади, активізації окремих людей, меценатів з метою протидії хворобі.

Задля запобігання поширенню вірусу в Україні, як і в усьому світі, був запроваджений карантин, який накладає обмеження на роботу підприємств, організацій у багатьох сферах, як у державному, приватному, так i в громадському секторі. Карантинні заходи ускладнили реалізацію типових форм волонтерства. Тому постають питання: Як в умовах COVID-19 працюють волонтери? Чи змінилися практики волонтерської діяльності Україні та чи відповідають ці зміни зарубіжному досвіду? В яких сферах відбувся спад діяльності, в яких - унеможливилася реалізація, а в яких волонтерство продовжує нормально функціонувати? Як реагують на змінені умови організації, що залучають волонтерський ресурс? Чи припиняють роботу організації, або ж вводять інноваційні форми волонтерства? Дослідження особливостей реалізації волонтерської діяльності в умовах COVID-19 важливе не лише через брак достовірних даних у цьому питанні, але й з огляду на потребу розуміння ролі волонтерського сектору у формування стійкості для запобігання, реагування на системні кризи та відновлення від них, що повинно стати основним елементом управління суспільством (Wernli et. al., 2021).

\section{Аналіз останніх досліджень і публікацій}

Зарубіжні та українські дослідження останнього року засвідчують активізацію громадянського суспільства у зв’язку з кризою, яку спричинило поширення COVID-19 та недостатність й неефективність інституційної політики 
(Blades et al., 2020; Mao et al., 2020). Зросла кількість заявок на участь у волонтерських програмах як міжнародних, так і українських організацій.

Дослідження, проведене у квітні 2020 р. австралійською організацією «Volunteering Victoria» (Volunteering Victoria, 2020) показує як змінилися потреби волонтерських організацій під час COVID-19: 36\% організацій припинили всі волонтерські послуги, 25\% не залучали щодних волонтерських ресурсів і $14 \%$ організацій змінили звичні форми та напрямки волонтерства. 3 одного боку, карантинні обмеження унеможливили традиційні форми волонтерства, з іншого набуло розвитку віртуальне волонтерство, яке може послабити тиск на працівників, які продовжують виконувати свої професійні обов'язки (лікарів, освітян, соціальних працівників), зменшити ризик вірусної інфекції та забезпечити відчуття нормальності для тих, хто потребує допомоги. У звіті найбільшого грантодавця США «Fidelity Charitable» (Fidelity Charitable, 2020) зазначається, що волонтери більш ніж в половину скоротили надання послуг під час пандемії, 66\% опитаних заявили, що їх волонтерська діяльність або припинилася взагалі, або зменшилась. Серед тих, хто продовжив волонтерську діяльність, дві треті звернулися до віртуальних або віддалених можливостей. Але $64 \%$ тих, хто не пробував волонтерити віртуально чи віддалено, просто не мали інформації як знайти такі види волонтерства. Результати звіту свідчать про те, що зменшення рівня волонтерства може бути тимчасовим, і майже три чверті волонтерів заявили, що планують повернутися до допандемічного рівня волонтерства, коли це буде безпечно.

Віртуальне волонтерство має як переваги, так і обмеження. Зокрема, дослідження ставлення дорослих до віртуального волонтерства під час пандемії COVID-19 засвідчує, що в програмах віртуального репетиторства окремої уваги потребує питання особливостей залучення людей похилого віку, врахування попереднього досвіду використання інформаційно-комунікаційних технологій та можливі труднощі зі встановленням особистого зв'язку репетиторів зі своїми учнями в Інтернеті (Sun et al., 2020).

В Україні ми також спостерігаємо зміни у напрямках i формах волонтерства, про що свідчать згадки у ЗМІ (Комарова, 2020; Богатікова, 2020). По-перше, почали з'являтися волонтерські організації, які пропонували свою волонтерську допомогу людям, які цього потребують у зв'язку із карантинними обмеженнями: спільноти, де люди можуть розповісти про потреби і знайти допомогу, доставка продуктів першої необхідності, безкоштовні перевезення та інша допомога. По-друге, значна частина волонтерських організацій були змушені припинити свою діяльність, а деякі змінювали повністю структуру організації і починали нову справу, актуальну та дозволену під час пандемії, як то підтримка людей на відстані за допомогою телефонних розмов (Сорокопуд, 2020). «Детектор медіа» в межах спецпроекту «Громадянське суспільство» у червні 2020 р. опитали керівників найбільш відомих благодійних і волонтерських організацій. Усі вони визнали, що складнощі та обмеження, які внесла пандемія, змінили діяльність організацій. Дехто повністю перейшов у формат онлайн, дехто змінив напрямок, деякі проекти неможливо реалізувати в умовах карантину, тому 
вони відклалися на потім. Але всі зазначили, що робота продовжується і їм вдалося підлаштуватися під нові умови (Тягнирядно, 2020).

Згідно $з$ дослідженням U-Report (U-Report, 2020), станом на серпень 2020 p. $57 \%$ опитуваних зазначили, що у зв'язку з карантином їх волонтерська діяльність ніяк не змінилася, але $17 \%$ повідомили про зменшення активності, а $20 \%$ взагалі припинили свою роботу. В нових умовах, фактично, звичним стає віртуальне (онлайн, е-волонтерство) волонтерство. Водночас, відзначається амбівалентний характер цифровізації під час пандемії, що пов'язаний як 3 підтримуючими функціями IКТ в діяльності некомерційних структур, так і $з$ ще більшим посиленням цифрових розривів, особливо серед уразливих і маргіналізованих верств населення (Башева та Єрмолаєва, 2020).

Важливим $є$ також розуміння характеру викликів, які постали перед волонтерськими організаціями, та якості змін їх діяльності. Державні та громадські організації, що реалізують волонтерські програми на сході України, в рамках карантинних обмежень, спричинених пандемією COVID-19 (Liakh et al., 2021), стикаються $з$ проблемами двох типів: організаційні (труднощі з доїздом волонтерів до місця роботи; нестабільність / плинність волонтерів; обмеження надання волонтерських послуг в офлайн; збільшення навантаження на спеціалістів організації з підготовки волонтерів до онлайн-роботи та ін.) та методологічні (труднощі в мотивації молоді до участі у довгострокових волонтерських програмах, орієнтованість програм навчання волонтерів на режим офлайн, відсутність досвіду підготовки волонтерів у онлайн-форматі, відсутність досвіду набору волонтерів в Інтернеті, труднощі у забезпеченні платформи для неформального спілкування волонтерів; відсутність можливості для інтер- та супервізії волонтерської діяльності та ін.).

Вищезазначені публікації засвідчують вплив пандемії COVID-19 на волонтерську діяльність, однак результати їх аналізу $є$ неоднозначними: $\epsilon$ свідчення як активізації волонтерської діяльності, так і іiі спаду. Потреба у кращому розумінні особливостей волонтерської діяльності в Україні в умовах CORONA-кризи обумовили цілі нашого дослідження.

Мета статті - охарактеризувати стан і визначити зміни, що відбулися в діяльності волонтерських організацій в умовах COVID-19. Завдання дослідження включали: з'ясувати поширеність різних форм і напрямків волонтерської діяльності в умовах введення карантинних заходів, пов'язаних із поширенням COVID-19; виявити труднощі у функціонуванні волонтерської діяльності в умовах COVID-19; з'ясувати, чи з'явилися нові можливості у реалізації волонтерської діяльності в умовах COVID-19.

\section{Методологія дослідження}

Дослідження проводилось у два етапи. На першому етапі був проведений аналіз даних про наявні в Україні волонтерські організації, здійснено пошук та відбір актуальних контактів потенційних учасників опитування, передбаченого другим етапом дослідження. Вибірка формувалась 3 переліку організацій, які залучають добровольців у різних напрямках діяльності та зареєстровані як волонтерські (інформація про них доступна на офіційному сайті Міністерства 
соціальної політики України), а також організацій, які ведуть активну діяльність та мають офіційні сторінки у соціальній мережі Facebook. До опитування, здійснюваного за дотриманням принципів інформованої згоди i захисту персональних даних учасників дослідження, запрошували волонтерів, активних щонайменше останніх 16 місяців.

Опитувальник був основним методом збору емпіричних даних про особливості здійснення волонтерської діяльності в період впровадження карантинних заходів. Він містив питання закритого, напіввідкритого та відкритого типу та складався 3 чотирьох основних блоків. Перший блок містив питання, направлені на вивчення загальної структури та видів організацій, які взяли участь у дослідженні. Питання другого блоку допомогли визначити труднощі у функціонуванні волонтерської діяльності в умовах COVID-19. Третій блок мав найбільшу кількість відкритих питань та був направлений на визначення змін, які відбулися у волонтерській діяльності у зв'язку із запровадженням карантину. Четвертий блок передбачав визначення нових можливостей, які відкрилися завдяки новим викликам, які спричинила ситуація 3 пандемією в цілому.

\section{Основні результати}

\section{Організації, які залучають волонтерів}

Згідно 3 даними, розміщеними на офіційному ресурсі Міністерства соціальної політики, на момент проведення дослідження в Україні зареєстровано 576 організацій та установ, що залучають до своєї діяльності волонтерів, зокрема іноземців та осіб без громадянства для провадження волонтерської діяльності на території України (Міністерство соціальної політики України, 2021).

Проте, в процесі аналізу було виявлено, що у $12 \%$ зареєстрованих організацій відсутні контактні дані, а саме електронні поштові скриньки, а $47 \%$ електронних адрес вказані невірно, або мають обмеження в отриманні вхідних листів. Це унеможливило опитування майже $60 \%$ організацій. Також, дані про веб-сайти в мережі Інтернет відсутні у $59 \%$ організацій із загального переліку. Контент-аналіз веб-сторінок організацій засвідчив відсутність нових публікацій протягом часу більше ніж рік - можна припустити, що значна частина громадських організацій припинили свою діяльність. Також у списку Міністерства соціальної політики України є такі установи, інформація про які відсутня в Інтернет середовищі взагалі; це може свідчити про фактичну відсутність діяльності та наявність організації лише «на папері». 3 цього можна зробити висновок, що подана на сайті Міністерства соціальної політики України інформація не відображає дійсний стан волонтерства та потребує актуалізації.

3 надісланих 236 листів на електронні пошти організацій, з якими можна було встановити електронний зв'язок, було отримано лише 15 відповідей, а це $6 \%$ 3 відправлених листів і всього майже $3 \%$ від загальної кількості офіційно зареєстрованих організацій. Така кількість респондентів, на жаль, не дає змоги отримати об'єктивних результатів. Тому, для формування більш репрезентативної вибірки, наступних респондентів було залучено завдяки соціальній мережі Facebook. 
Додатковим джерелом про волонтерські організації були дані, зібрані «Українською Волонтерською Службою» (УВС), яка від початку пандемії до основних напрямів діяльності додала напрям боротьби з поширенням COVID-19 та подолання його наслідків. Крім основної роботи, УВС здійснювала моніторинг тих організацій, які реально працюють в період карантину та активно залучають волонтерський ресурс. Більшість 3 цих організацій не $\epsilon$ офіційно зареєстровані та не входять до списку Міністерства соціальної політики України. Список складався з громадських організацій, активних груп взаємодопомоги, державних закладів, медичних установ та компаній, гарячих ліній та телефонних служб, до яких можна звернутися за безкоштовною допомогою; до нього входили як представники об'єднань мешканців певної громади, так i міжобласні та всеукраїнські організації.

Таблиця 1: Організації, які активно залучають волонтерів під час карантину (за даними «Української Волонтерської Служби»)

\begin{tabular}{|c|l|c|}
\hline № & \multicolumn{1}{|c|}{ Напрям діяльності організації } & Кількість \\
\hline 1 & Надання соціальних послуг громадянам, які перебувають у СЖО & $39 \%$ (30) \\
\hline 2 & Допомога у боротьбі з СОVID-19 та його наслідками & $20 \%$ (15) \\
\hline 3 & $\begin{array}{l}\text { Участь у подоланні наслідків та надання допомоги жертвам } \\
\text { війни }\end{array}$ & $14 \%$ (11) \\
\hline 4 & Охорона здоров'я, материнства та дитинства & $10 \%$ (8) \\
\hline 5 & Розвиток та популяризація волонтерської діяльності & $6 \%$ (5) \\
\hline 6 & Безоплатна правова допомога та захист прав людини & $4 \%(3)$ \\
\hline 7 & $\begin{array}{l}\text { Організація дозвілля для дітей та юнацтва, національно- } \\
\text { патріотичне виховання }\end{array}$ & $3 \%$ (2) \\
\hline 8 & Волонтерство у сфері освіти & $1 \%$ (1) \\
\hline 9 & Охорона навколишнього природного середовища & $\mathbf{1 0 0 \%}$ \\
\hline & $\mathbf{7 7}$ \\
\hline
\end{tabular}

Можна вважати, що наведена вище таблиця, окрім кількості волонтерських організацій, які активно працюють під час карантину, відображає найбільш поширені напрямки роботи, до яких залучають волонтерів. 
У анкетуванні, проведеному на наступному кроці дослідження, взяло участь 35 осіб із визначеного переліку організацій. Подана нижче таблиця відображає структуру та вид організацій, які взяли участь в опитуванні.

Таблиця 2: Характеристики організацій, які взяли участь в опитуванні $(\mathbf{N}=\mathbf{3 5})$

\begin{tabular}{|c|c|c|}
\hline Характеристика & Параметр & Кількість \% (n) \\
\hline \multirow{4}{*}{$\begin{array}{c}\text { Як організації } \\
\text { залучають } \\
\text { волонтерський } \\
\text { ресурс: }\end{array}$} & на постійній основі & $54 \%(19)$ \\
\hline & до деяких проектів & $34 \%(12)$ \\
\hline & залучали до пандемії, але тепер припинили & $9 \%(3)$ \\
\hline & почали залучати на час пандемії & $3 \%(1)$ \\
\hline \multirow{4}{*}{$\begin{array}{c}\text { За масштабами } \\
\text { діяльності } \\
\text { організації: }\end{array}$} & локальна & $35 \%(12)$ \\
\hline & регіональна & $17 \%(6)$ \\
\hline & національна & $25 \%(9)$ \\
\hline & міжнародна & $23 \%(8)$ \\
\hline \multirow{4}{*}{$\begin{array}{c}\text { Якщо організація } \\
\text { локальна або } \\
\text { регіональна, то } \\
\text { вона функціонує } \\
\text { в такій області } \\
\text { країни: }\end{array}$} & Львівська & $17 \%(6)$ \\
\hline & Київська & $20 \%(7)$ \\
\hline & Дніпропетровська & $9 \%(3)$ \\
\hline & $\begin{array}{l}\text { Волинська } \\
\text { Закарпатська } \\
\text { Запорізька } \\
\text { Івано-Франківська } \\
\text { Одеська } \\
\text { Рівенька } \\
\text { Тернопільська }\end{array}$ & по $3 \%$ (1) \\
\hline \multirow{2}{*}{$\begin{array}{c}\text { За порядком } \\
\text { фінансування } \\
\text { організація: }\end{array}$} & дотаційна & $29 \%(10)$ \\
\hline & автономна & $71 \%(25)$ \\
\hline \multirow{3}{*}{$\begin{array}{c}\text { За кількісним } \\
\text { складом } \\
\text { організації: }\end{array}$} & малочисельна (до 10 осіб) & $37 \%(13)$ \\
\hline & середня (10-30 осіб) & $40 \%(14)$ \\
\hline & чисельна (більше 30 осіб) & $23 \%(8)$ \\
\hline
\end{tabular}


Отже, в опитуванні взяли участь організації, більша частина з яких залучає волонтерів на постійній основі; за масштабами діяльності в більшості випадків організації локальні та функціонують у Львівській та Київській областях. За порядком фінансування більша частина організацій автономні. А за кількісним складом - малочисельні або середньо чисельні (до 30 осіб).

\section{Поширеність різних напрямів волонтерської діяльності}

Наведена нижче діаграма (рис. 1) відображає найбільш поширені напрямки волонтерської діяльності.

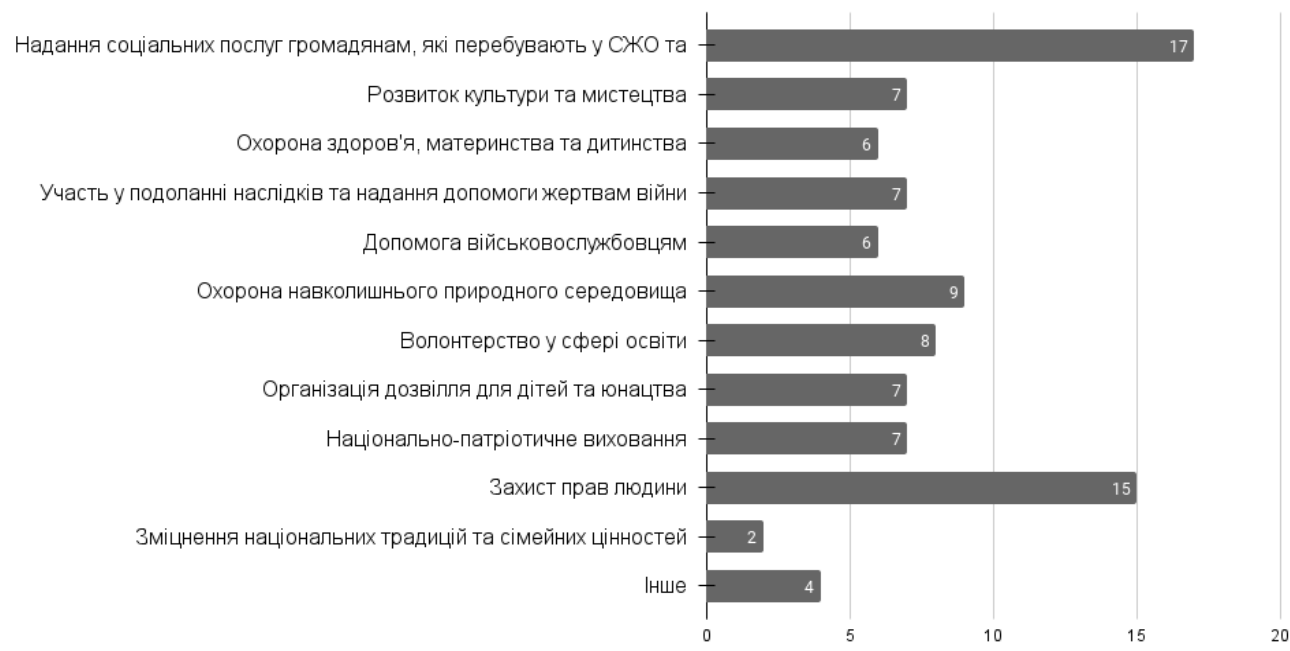

Рисунок 1. Напрями волонтерської діяльності в умовах введення карантинних заходів, пов'язаних із поширенням COVID-19 $(N=35)$

48\% (17) організацій зазначили у якості основного напряму у своїй діяльності надання послуг громадянам, які перебувають у складних життєвих ситуаціях та потребують сторонньої допомоги. До провідних напрямів можуть бути також віднесені: захист прав людини та надання безоплатної правової допомоги - 40\% (14), охорона навколишнього природного середовища, в тому числі захист тварин - 26\% (9), волонтерство у сфері освіти - 23\% (8). Лише 20\% (7) опитаних організацій беруть участь у подоланні наслідків та надання допомоги жертвам війни, допомагають військовослужбовцям.

\section{Труднощі та зміни волонтерської діяльності в умовах COVID-19}

$26 \%$ (9) опитаних визнає, що у зв'язку з введенням карантину зіткнулися 3 суттєвими труднощами; 54\% (19) зазначають, що складнощі присутні, хоч i незначні; лише 20\% (7) респондентів відзначили, що у зв'язку 3 введенням карантину у роботі волонтерів складнощі не виникають. В цілому волонтерська діяльність з початком пандемії COVID-19 змінилася для 54\% (19) організацій, серед них 37\% (13) зазначили, що зміни відбулися, але не надто значні, а для 17\% (6) діяльність змінилася кардинально. Для 40\% (13) опитаних діяльність 
залишилась майже незмінною, пандемія внесла лише часткові зміни; решта 17\% (6) зазначили, що змін не відбулося.

На діаграмі (рис. 2) можна побачити, яких змін зазнала робота волонтерських організацій під час карантину.

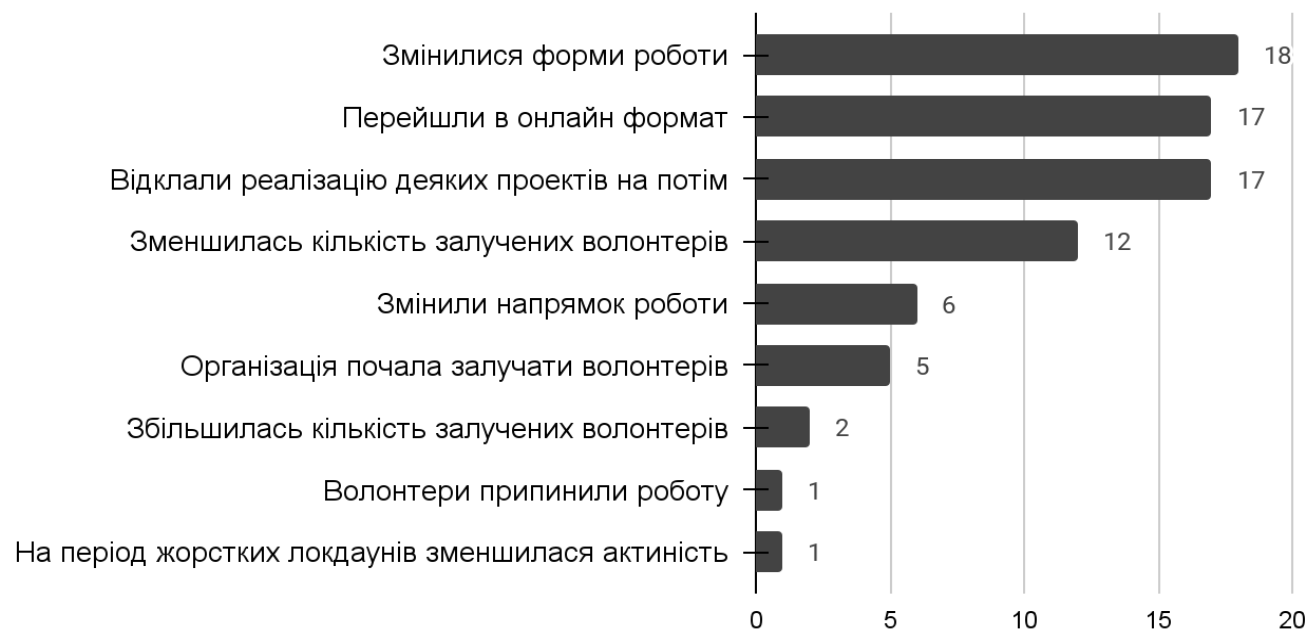

Рисунок 2. Зміни, які відбулися в волонтерських організаціях у зв'язку з введенням карантинних заходів $(N=35)$

51\% (18) організацій задля того, щоб зменшити тиск карантинних обмежень, були змушені змінити форми роботи, 48\% (17) перейшли на дистанційний формат роботи та відклали реалізацію деяких проектів на потім, 34\% (12) організацій зменшили кількість залучених волонтерів.

Очевидно, що у зв'язку 3 карантином змінилося волонтерство, яке передбачає прямий контакт з отримувачем послуг - 17\% (6) опитаних організацій були змушені припинити надання послуг. Організації, які все ж продовжують діяльність, ввели додаткові заходи безпеки. Носіння захисних масок або респіраторів та використання антисептичних засобів стало звичним для 48\% (17) волонтерів, а дотримання дистанції стало обов'язковим для $40 \%$ (14) респондентів. 31\% (11) громадських організацій ввели додаткові обмеження припинили проведення масових заходів та акцій за участю більш як 20 осіб. 9\% (3) організацій припинили залучати нових волонтерів до роботи, а 6\% (2) проводили постійний температурний скринінг.

В карантинних умовах формат дистанційної роботи та Е-волонтерство набули більшого поширення, ніж у попередні роки. В усіх сферах, де це можливо, організації намагалися перевести роботу, хоч і частково, у віддалений формат. Проте, 26\% (9) організацій і надалі не практикують дистанційне волонтерство. $37 \%$ (13) організацій посилили дистанційний формат роботи (розширили перелік засобів дистанційного зв'язку та комунікації, розвинули навички дистанційної роботи волонтерів тощо). Серед організацій, які до пандемії не практикували дистанційне волонтерство, 34\% (12) запровадили дистанційний формат роботи 3 
використанням інтернет ресурсів, а 11\% (4) ввели волонтерство на відстані 3 використанням телефонного зв'язку. Повністю перевели роботу у формат Еволонтерства 9\% (3) організацій.

Отже, для значної кількості активних, діючих організацій діяльність із запровадження карантинних обмежень змінилася кардинально. Серед ключових змін, яких зазнала діяльність волонтерських організацій: зміна форми роботи; перехід у дистанційний формат роботи; відстрочення реалізації проектів на майбутнє; зменшення кількості залучених волонтерів. Водночас, 46\% (16) організацій не помітили змін, або оцінюють ї як незначні. Але майже у всіх випадках були присутні певні труднощі, які хоч i тимчасово, але внесли корективи у звичну роботу.

\section{Нові можливості у реалізації волонтерської діяльності}

Ситуація, яка склалася у зв'язку з пандемією, виявилась для волонтерських організацій не лише ситуацією обмежень і труднощів; 54\% (19) опитаних засвідчили появу нових можливостей, $57 \%$ (20) - відкриття нових напрямів та $26 \%$ (9) - нових форм роботи.

Майже половина опитаних організацій - 46\% (16) - головним відкриттям цього періоду визначили «онлайн», а також залучення нових добровольців. Як виявилося, робота волонтерів у віртуальному просторі має багато переваг. Як мінімум, це полегшує організацію та проведення різних онлайн-акцій, освітніх та інших проектів. Також дистанційний формат економить час на пересування, полегшує комунікацію та збільшує час на реалізацію основних напрямів діяльності. Загалом 43\% (15) респондентів оцінюють ситуацію, в якій опинилась їхня організація та робота волонтерів у зв'язку з пандемією, як ситуацію можливостей, 26\% (9) - як ситуацію обмежень і 31\% (11) залишаються нейтральними.

Волонтери навчилися співпрацювати з органами державної адміністрації та іншими організаціями, а не тільки 3 безпосередньо 3 отримувачами послуг. Інтернет допоміг охопити більшу кількість громадян та зменшити недовіру до дистанційної роботи спеціалістів. «Всі вже звикли праџювати онлайн, а це відкриває більше можливостей для всеукраӥнської та міжнародної співпрачі, тому волонтерство має більще ресурсів для розвитку» - зазначив один 3 респондентів у своїй анкеті.

Переконані, що пандемія COVID-19 і впровадження локдауну матимуть довгострокові наслідки, ми також спробували з'ясувати, як ставляться до цих змін самі волонтерські організації. Не можна стверджувати, що зміни діяльності волонтерів після зняття карантинних обмежень тотально оцінюються як критичні і незворотні: 43\% (15) опитаних зазначили, що повернуться до «докарантинного формату», 34\% (12) будуть залучати більше волонтерів до своєї діяльності і $31 \%$ (11) зазначили, що будуть по-іншому організовувати роботу залучених добровольців. 
8

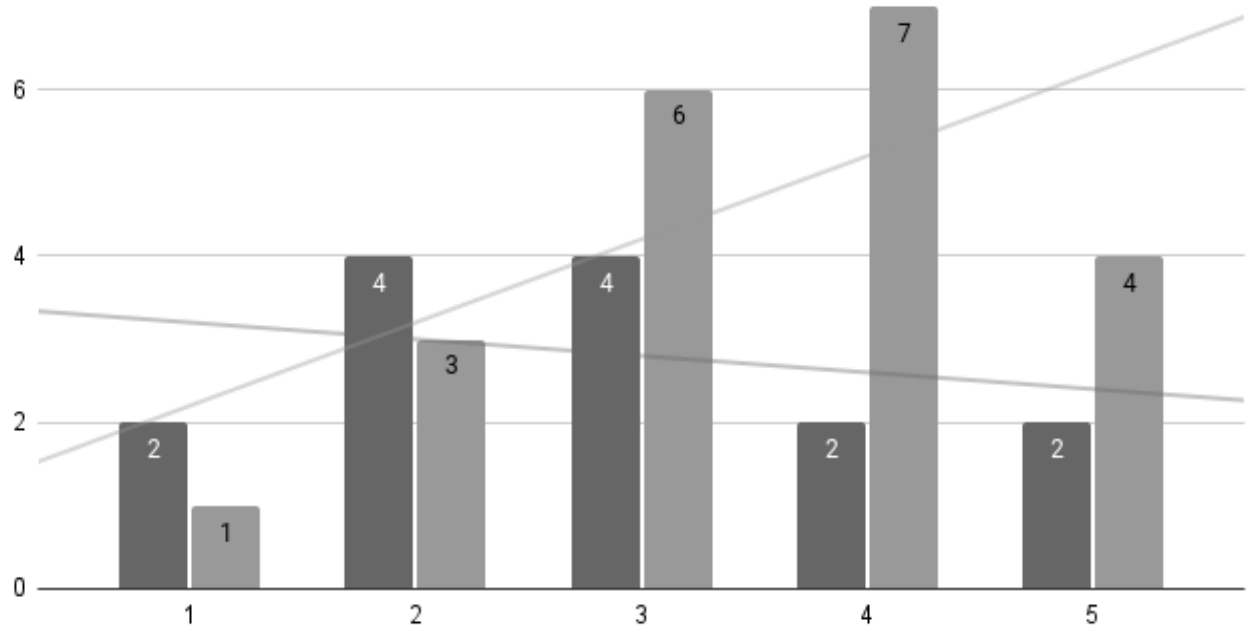

Рисунок 3. Зведені дані оцінки волонтерськими організаџіями ситуаџіï, в якій вони опинилась у зв'язку з пандемією, та роботи волонтерів (горизонтальна вісь, де 1 - «ситуація обмежень», 5 - «ситуація можливостей»), $i$ оцінки подальших перспектив зміни діяльності волонтерів після зняття карантинних обмежень (повернення до «докарантинного формату» чи зміна діяльності).

Як видно 3 рис. 3, організації, які оцінюють ситуацію провадження діяльності в умовах пандемії швидше як ситуацію можливостей, в меншій мірі розглядають перспективу повернення до «докарантинного формату». Можемо припустити, що саме ці організації змогли скористатися перевагами ситуації та інтегрувати позитивний досвід волонтерської роботи за нових умов в історію свого розвитку.

\section{Обговорення результатів}

Результати проведеного дослідження не можна вважати універсальними для України через очевидні обмеження репрезентативності вибірки, обумовлені, передусім тим, що збір даних проводився під час локдауну з використанням засобів електронної комунікації. Водночас, сам факт недоступності більше половини офіційно зареєстрованих волонтерських організацій в умовах карантину також $є$ цікавим результатом дослідження, оскільки може свідчити про низький рівень цифровізації діяльності українських волонтерських організацій в цілому, відсутність альтернативних каналів комунікації 3 широкою громадськістю та їх бенефіціарами, клієнтами зокрема. Врешті, пандемічна криза, певною мірою, виконала функцію індикатора спроможності - чи навіть власне 
наявності - громадянського суспільства, оголила слабкі сторони розвитку неурядового сектору та виявила недоліки державно-громадської взаємодії.

Порівняння даних УВС і результатів власного опитування дозволяє зробити висновок, що провідним напрямом діяльності українських волонтерських організацій залишається надання соціальних послуг громадянам, які перебувають у СЖО. Те, що респонденти не вказали допомогу у боротьбі з COVID-19 та його наслідками як окремий напрям діяльності, може бути пояснено тим, що його включали у попередній пункт, 3 огляду на широту самого поняття «складні життєві обставини». Крім того, у вибірці опитуваних було значно більше представників організацій, які займаються захистом прав людини та наданням безоплатної правової допомоги, охороною навколишнього природного середовища і волонтерством у сфері освіти.

Результати опитування в частині визначення труднощів та змін у реалізації діяльності, певною мірою, співпадають із даними подібних досліджень роботи соціальних організацій в умовах пандемії. Зокрема, типовими виявились проблеми, зумовлені карантинними заходами: потреба в закупівлі гігієнічних засобів; труднощі з приїздом співробітників на роботу, здійсненням доставок; обмеження надання соціальних послуг у закладі тощо (Карагодіна, Пожидаєва та Семигіна, 2020). Окремої уваги заслуговує питання зміни комунікації в період пандемії через обмеження контактного спілкування (Плахова та Карчова, 2021). Організаційні зміни, в тому числі ті, що вимагають перебудови системи комунікацій, зазвичай, тривають роками, однак екстраординарна пандемічна ситуація вимагала швидкої адаптації і стимулювала організації активно розвивати нові моделі та впроваджувати інструменти дистанційної комунікації. В цілому, розвиток е-волонтерства та пов'язаних з дистанційними формами спілкування волонтерські проекти і програми можна вважати позитивною стороною досвіду, отриманого під час обмежувальних карантинних заходів, викликаних пандемією COVID-19 (Liakh et al., 2021). Водночас, такі зміни пов'язані з ризиками підвищеного комунікативного навантаження на працівників, потребою у створенні для них систем навчання та підтримки. Як зазначають російські дослідниці (Башева та Єрмолаєва, 2020, 378), «цифровізація волонтерської роботи відбувається вже давно, а нинішня криза лише прискорила iіi, породивши ряд нових проблем, таких як «цифрове вигорання».

Варто також відзначити високий відсоток організацій, орієнтованих на повернення до «докарантинного формату», що, ймовірно, може бути пояснено загальним ставленням до ситуації пандемії COVID-19 як до надзвичайної, неочікуваної і короткотермінової, що спричиняє прагнення до відновлення стану, повернення до системи взаємовідносин і внутрішнього балансу особистості, що передували катастрофічній події (Гаркавенко, 2018).

\section{Висновки}

Волонтерська діяльність, в цілому, - явище досить гнучке, вона може змінюватися відповідно до подій у світі та потреб населення. Наразі в Україні склалася ситуація, яка вимагає адаптації волонтерських проектів та програм до нових реалій. 
Представлене дослідження включає результати аналізу та порівняння емпіричних даних про основні види та напрямки волонтерства в умовах COVID19, зібрані з різних джерел (самі волонтери та організації, які їх залучають, розвивають культуру волонтерства в Україні, органи державної влади). В цілому можна стверджувати, що із виявленням вірусу Sars-Cov-2 в Україні волонтерський сектор, фактично, переживає стан кризи - зламу традиційних уявлень про зміст та форми самої діяльності. Спостерігається часткова зміна пріоритетних напрямів волонтерства: надання соціальних послуг громадянам, які перебувають в складних життєвих обставинах, у тому числі допомога у боротьбі 3 COVID-19 та його наслідками, захист прав людини і волонтерство у сфері освіти дещо «відсунули на задній план» популярні раніше допомогу жертвам війни, військовослужбовцям, просвітницькі та культурно-мистецькі волонтерські проекти і програми.

Опитування представників організацій, які залучають добровольчий ресурс, проведене в травні-червні 2021 року, засвідчило зміни в діяльності більш ніж половини з них. Серед основних змін, які відбулися у зв'язку з введенням карантинних заходів, можна виділити наступні: зміни форм та напрямів роботи; зміни у реалізації проектів; зміни, пов'язані з кількістю залучених волонтерів. Виявлено як низку проблем, зумовлених карантинними обмежувальними заходами (неможливість організовувати діяльність, яка передбачає прямий контакт, потреба в забезпеченні засобами індивідуального захисту, зменшення кількості залучених волонтерів, відмова від проведення деяких заходів, або відкладення ї реалізації на невизначений час), так і позитивні зрушення в діяльності організацій (поява нових напрямків та можливостей в реалізації волонтерської діяльності).

Світовий досвід засвідчує, що в умовах надзвичайних ситуацій волонтерський сектор відіграє важливу роль, активізуючи та посилюючи місцеві системи підтримки і самодопомоги. Відтак подальшого вивчення потребують питання громадської участі на локальному рівні. Окремої уваги заслуговує дослідження стану і особливостей розвитку Е-волонтерства в Україні.

\section{Література}

Башева, О. А. \& Ермолаева, П. О. (2020). Цифровизация деятельности российских волонтеров в чрезвычайных ситуациях: влияние пандемии или самостоятельный тренд развития? Мониторинг общественного мнения: экономические и социальные перемены, 6: 376-402. doi https://doi.org/10.14515/monitoring.2020.6.1746.

Богатікова, М. (2020). «Соціальна доставка», StopCovid та інші. Як епідемія змінюе волонтерський рух в Україні. Громадське Телебачення, 11 вересня, 2020. Retrieved from: https://hromadske.ua/posts/socialna-dostavka-stopcovid-ta-inshi-yak-epidemiya-zminyuyevolonterskij-ruh-v-ukrayini (02.04.2021).

Гаркавенко, 3. (2018). Рецензія на посібник «Психосоціальна підтримка в умовах надзвичайних ситуацій: підхід резилієнс : навч.-метод. посіб.» (ред. Н. Гусак). Вісн. Акад. праці, соц. відносин і туризму, 2: 93-95.

Горєлов, Д. М. \& Корнієвський, О. А. (2015). Волонтерський рух: світовий досвід та украӥнські громадянські практики: аналіт. доп. Київ: НІСД. 
Карагодіна, О., Пожидаєва, О. \& Семигіна, Т. (2020). Практика соціальної роботи в умовах карантинних обмежувальних заходів: швидка оцінка та уроки. Social work and education, 7 (4): 452-465. doi: https://doi.org/10.25128/2520-6230.20.4.4.

Козачук, М. Б. (2016). Нові види волонтерства в Україні як відповідь на виклики часу. Вісник НТУУ «КПІ». Політологія. Соціологія. Право : збірник наукових пращьь, 1/2 (29/30): 52-57.

Комарова, О. (2021). Знову на передову: волонтери проти корона вірусу. Padio Свобода, 19 березня 2020. Retrieved from: https:/www.radiosvoboda.org/a/coronavirus-covidvolontery-ukraina/30497602.html (02.04.2021).

Міністерство соціальної політики України (2021). Інформація про організації та установи, що залучають до своєї діяльності волонтерів, зокрема іноземців та осіб без громадянства для провадження волонтерської діяльності на території України. Доступно з: https://www.msp.gov.ua/files/volonterstvo/576.xlsx (26.03.2021).

Павлюк, К. С. (2015). Волонтерський рух: зарубіжний досвід та вітчизняні практики. Інвестииї: практика та досвід, 13-14: 87-93.

Паславська, О. (2016). Становлення та розвиток волонтерського руху в Україні (історико-правове дослідження). Актуальні проблеми правознавства, 4 (8): 22-28.

Плахова, О. М., \& Карчова, О. М. (2021). Особливості комунікації в соціальній роботі в умовах пандемії Covid-19. SOCIOПРОCTIP: Міждисциплінарний електронний збірник наукових праць з соціологіі та соціальної роботи, 11: 17-22. dоі: https://doi.org/10.26565/2218-2470-2021-11-02.

Проценко, О. О. (2021). Волонтерські практики в умовах вимушеної міграції в сучасній Україні: чинники та наслідки актуалізації (Дис. канд. соціол. наук). Харківський національний університет імені В. Н. Каразіна МОН України, Харків.

Сорокопуд, Н. (2020). 7000 українців погодилися підтримати людей на самоті під час пандемії COVID-19. ЮНICЕФ, 4 грудня 2020. Retrieved from: https://www.unicef.org/ukraine/press-releases/7000-volunteers-supported-lonely-people (02.04.2021).

Тягнирядно, Л. (2020). У кризах волонтери та благодійники стають більш ефективними. ДЕТЕКТОР МЕДІА: ЗМІ для змін, 8 червня 2020. Retrieved from: https://zz.detector.media/community/texts/177803/2020-06-08-u-kryzakh-volontery-tablagodiynyky-stayut-bilsh-efektyvnymy/ (02.04.2021).

Чайка, І. Ю. (2017). Волонтерство: сутність феномена та особливості його функціонування в сучасній Україні. Науково-теоретичний альманах «Грані», 20; 7(147): 72-79. doi: https://doi.org/10.15421/171798.

Blades, A., Concustell, A., Duran, A., Pérez, R. \& Portilla, F. (2020). La solidaritat i el voluntarisme durant la crisi de la COVID-19. Perifèria, revista de recerca i formació en antropologia, 25(2), 115-129. doi: https://doi.org/10.5565/rev/periferia.790.

Fidelity Charitable (2020). The Role of Volunteering in Philanthropy. Retrieved from: https://www.fidelitycharitable.org/content/dam/fc-public/docs/resources/the-role-of-volunteeringin-philanthropy.pdf (22.03.2021).

Liakh, T., Lekholetova, M., Kotelevets, A., Spirina, T. \& Shved, O. (2021). Development of Youth Volunteer Programs in the Condition of the Covid-19 Pandemic in the Communities, Neighboring to the Area of the Joint Forced Operation in the East of Ukraine. In Society, integration, education. Proceedings of the International Scientific Conference, May 28th-29th, 2021, Rezekne, 3: 316-326. doi: https://doi.org/10.17770/sie2021vol3.6334.

Mao, G., Fernandes-Jesus, M., Ntontis, E. \& Drury, J. (2020). What have we learned so far about COVID-19 volunteering in the UK? A rapid review of the literature (preprint). doi: https://doi.org/10.1101/2020.11.22.20236059. 
Pyrlik, G. (2020). How volunteers are spearheading Ukraine's COVID-19 response. OpenDemocracy. April, 20, 2020. Retrieved from: https://www.opendemocracy.net/en/odr/volunteers-ukraine-coronavirus-response/ (4.04.2021).

Sun, P., Morrow-Howell, N., Pawloski, E., Swinford, E. (2020). Older Adults' Attitudes Toward Virtual Volunteering During the COVID-19 Pandemic. Innovation in Aging, 4(S1); 954. doi: https://doi.org/10.1093/geroni/igaa057.3489.

U-Report (2020). Волонтерство під час карантину: опитування. 20 серпня 2020. Retrieved from: https://ukraine.ureport.in/opinion/4513/ (02.04.2021).

Volunteering Victoria (2020). Volunteer Management During COVID-19. Retrieved from: https://www.volunteeringvictoria.org.au/wp-content/uploads/2020/04/Volunteerism-duringCOVID-19.pdf (22.03.2021).

Wernli, D., Clausin, M., Antulov-Fantulin, N., Berezowski J., Biller-Andorno, N., Blanchet, K., Böttcher L., et al. (2021). Governance in the age of complexity: Building resilience to COVID19 and future pandemics. Geneva Science-Policy Interface Policy Brief. Geneva, Switzerland. 


\section{VOLUNTEER ACTIVITIES IN UKRAINE AMIDST THE COVID-19 PANDEMIC}

Olha Baidarova, $\mathrm{PhD}$ in Psychology, Associate Professor at the Department of Social Rehabilitation and Social Pedagogy, Taras Shevchenko National University of Kyiv, Kyiv, Ukraine; baidarovao@knu.ua

Anastasia Dulgerova, Candidate of educational level "Master" in the Educational and Scientific Program "Social Pedagogy" of Taras Shevchenko National University of Kyiv, Kyiv, Ukraine; anastasiadyulgerowa@gmail.com

Abstract. The COVID-19 pandemic has become a serious challenge for Ukrainian society and has affected all spheres of activity, including volunteer activities of citizens. This article presents the results of the research on the state and peculiarities of the implementation of volunteer activities under COVID-19 conditions in Ukraine. The research was carried out in February-June 2021 using methods of metaanalysis of statistical data, questionnaires, and content analysis.

It was found that $60 \%$ of officially registered volunteer organizations stopped their activities or cannot be identified as actively working. Analysis and systematization of monitoring data provided by the Ukrainian Volunteer Service allowed us to identify 77 organizations of various types that actually work during the quarantine period and actively recruit volunteer resources. Formal and informal organizations that have public web pages with contact information for electronic listservs were interviewed by 35 people.

It was found that under quarantine conditions, the activities of the organizations that engage volunteer resources changed for $54 \%$ of the respondents, but despite the difficulties that $80 \%$ of the organizations experience, they continue to work. Inability to organize activities that involve direct contact with the recipient of the service, or the need for additional consideration of personal protection and safety equipment, both for the recipients of services and for the providers (volunteers), were the key difficulties in organizing the work of volunteers. Among the main changes, volunteers noted the change in the forms of work, the transition to a remote format, in particular in the Internet space, a reduction in the number of volunteers involved and the impossibility of conducting some activities, with postponement of implementation for an unspecified amount of time. It is noteworthy that most of the respondents assessed the quarantine situation as a situation of opportunities rather than restrictions, specifically, they noted the emergence of new areas of activity, one of which is assistance in combating the spread of the disease and counteracting the effects of COVID-19. 
Keywords: volunteering; COVID-19; lockdown; crisis; digitalization of volunteers' activities.

\section{References}

Basheva, O. A., \& Ermolaeva, P. O. (2020). Digitalization of the Russian Emergency Volunteers' Activities: a Pandemic Impact or an Independent Development Trend? Monitoring of Public Opinion: Economic and Social Changes, 6: 376-402. https://doi.org/10.14515/monitoring. 2020.6.1746 (In Russian).

Bogatikova, M. (2020). «Social delivery», StopCovid and others. How the epidemic is changing the volunteer movement in Ukraine. Public Television, September 11, 2020. Retrieved from: https://hromadske.ua/posts/socialna-dostavka-stopcovid-ta-inshi-yak-epidemiya-zminyuyevolonterskij-ruh-v-ukrayini (02.04.2021) (in Ukrainian).

Blades, A., Concustell, A., Duran, A., Pérez, R. \& Portilla, F. (2020). La solidaritat i el voluntarisme durant la crisi de la COVID-19. Perifèria, revista de recerca $i$ formació en antropologia, 25(2), 115-129. doi: https://doi.org/10.5565/rev/periferia.790.

Chaika, I. Y. (2017). Volunteerism: essence of the phenomenon and peculiarities of its functioning in modern Ukraine. Scientific and theoretical almanac «Grani», 20; 7(147), 72-79. doi: https://doi.org/10.15421/171798 (in Ukrainian).

Harkavenko, Z. (2018). Review of the manual «Psychosocial support in the context of emergency situations: resilience approach» (ed. N. Husak). Journal of the Academy of Labour, Social Relations and Tourism, 2: 93-95.

Horielov, D. M. \& Korniievskyi, O. A. (2015). The volunteer movement: world experience and ukrainian civil practice: an analytical report. Kyiv: The National Institute for Strategic Studies (in Ukrainian).

Fidelity Charitable (2020). The Role of Volunteering in Philanthropy. Retrieved from: https://www.fidelitycharitable.org/content/dam/fc-public/docs/resources/the-role-of-volunteeringin-philanthropy.pdf (22.03.2021).

Karagodina, O., Pozhydaieva, O. \& Semigina, T. (2020). Practice of social work in the conditions of quarantine restrictive measures: rapid appraisal and lessons. Social work and education 7 (4): 452-465. doi: https://doi.org/10.25128/2520-6230.20.4.4 (in Ukrainian).

Komarova, O. (2021). Back to the forefront: volunteers against coronavirus. Radio Liberty, March 19, 2020. Retrieved from: https://www.radiosvoboda.org/a/coronavirus-covid-volonteryukraina/30497602.html (02.04.2021) (in Ukrainian).

Kozachuk, M. B. (2016). New types of volunteering in Ukraine as a response to challenges. Collection of «NTUU «KPI» Bulletin». Political Science. Sociology. Law», 1/2 (29/30): 52-57 (in Ukrainian).

Liakh, T., Lekholetova, M., Kotelevets, A., Spirina, T. \& Shved, O. (2021). Development of Youth Volunteer Programs in the Condition of the Covid-19 Pandemic in the Communities, Neighboring to the Area of the Joint Forced Operation in the East of Ukraine. In Society, integration, education. Proceedings of the International Scientific Conference, May 28th-29th, 2021, Rezekne, 3: 316-326. doi: https://doi.org/10.17770/sie2021vol3.6334.

Mao, G., Fernandes-Jesus, M., Ntontis, E. \& Drury, J. (2020). What have we learned so far about COVID-19 volunteering in the UK? A rapid review of the literature (preprint). doi: https://doi.org/10.1101/2020.11.22.20236059

Ministry of Social Policy of Ukraine (2021). Information on organizations and institutions that involve volunteers in their activities, including foreigners and stateless persons to carry out volunteer activities in Ukraine. Retrieved https://www.msp.gov.ua/files/volonterstvo/576.xlsx (26.03.2021) (in Ukrainian). 
Pavliuk, K. The volunteer movement: an international experience and national practices. Investment: Practice and Experience, 13-14: 87-93 (in Ukrainian).

Paslavska, O. (2016). The formation and development of the volunteer movement in Ukraine (historical and legal research). Actual problems of jurisprudence, 4 (8): 22-28 (in Ukrainian).

Pyrlik, G. (2020). How volunteers are spearheading Ukraine's COVID-19 response. OpenDemocracy. April, 20, 2020. Retrieved from: https://www.opendemocracy.net/en/odr/volunteers-ukraine-coronavirus-response/ (4.04.2021).

Plakhova, O. \& Karchova, O. (2021). The features of communication in social work in the convention of the Covid-19 pandemic. SOCIOPROSTIR: The interdisciplinary online collection of scientific works on sociology and social work, 11: 17-22. doi: https://doi.org/10.26565/2218-24702021-11-02 (in Ukrainian).

Protsenko, O. O. (2021). Volunteering practices under conditions of forced migration in contemporary Ukraine: factors and consequences of their actualization (Cand. Sociol. Sci. Diss.). V. N. Karazin Kharkiv National University, Ministry of Education and Sciences of Ukraine, Kharkiv (in Ukrainian).

Sorokopud, N. (2020). 7,000 Ukrainians agreed to support lonely people during the COVID-19 pandemic. UNICEF, December 4, 2020. Retrieved from: https://www.unicef.org/ukraine/press-releases/7000-volunteers-supported-lonely-people (02.04.2021) (in Ukrainian).

Sun, P., Morrow-Howell, N., Pawloski, E., Swinford, E. (2020). Older Adults' Attitudes Toward Virtual Volunteering During the COVID-19 Pandemic. Innovation in Aging, 4(S1); 954. doi: https://doi.org/10.1093/geroni/igaa057.3489.

Tiahnyriadno, L. (2020). In crises, volunteers and philanthropists become more effective. DETECTOR MEDIA: Media for change, June 8, 2020. Retrieved from: https://zz.detector.media/community/texts/177803/2020-06-08-u-kryzakh-volontery-tablagodiynyky-stayut-bilsh-efektyvnymy/ (02.04.2021) (in Ukrainian).

U-Report (2020). Volunteering during quarantine: a survey. August 20, 2020. Retrieved from: https://ukraine.ureport.in/opinion/4513/ (02.04.2021) (in Ukrainian).

Volunteering Victoria (2020). Volunteer Management During COVID-19. Retrieved from: https://www.volunteeringvictoria.org.au/wp-content/uploads/2020/04/Volunteerism-duringCOVID-19.pdf (22.03.2021).

Wernli, D., Clausin, M., Antulov-Fantulin, N., Berezowski J., Biller-Andorno, N., Blanchet, $\mathrm{K}$., Böttcher L., et al. (2021). Governance in the age of complexity: Building resilience to COVID19 and future pandemics. Geneva Science-Policy Interface Policy Brief. Geneva, Switzerland.

\section{Article history:}

Received: August 08, 2021

1st Revision: September 07, 2021

Accepted: September 30, 2021 